\title{
Quality and problems of training managers for priority sectors of the economy
}

\author{
Margarita Ryazantseva $^{1 *}$ and Natalya Kiseleva $^{2}$ \\ ${ }^{1}$ Financial University under the Government of the Russian Federation, Department of HR \\ Management and Psychology, Moscow, Russia \\ ${ }^{2}$ Financial University under the Government of the Russian Federation, Center for Advanced \\ Research and Development in Education, Department of Sociology, Moscow, Russia
}

\begin{abstract}
New challenges of the modern economy and society require changes in russian state program for training managerial human resources. The purpose of the present research is to develop a methodology for monitoring the labor market to assess the training quality of managerial human resources and identify the needs of regions and employers in terms of improving the skills of managers. The research methodology is based on Russian and foreign practices. The empirical basis of the research includes the results of an expert telephone survey of employers who have sent their employees to study under the Program, as well as an online survey of graduates of the Program. The significance of differences in the assessments of competencies required by a contemporary manager between groups of respondents was carried out using the nonparametric MannWhitney U-test. The article presents the authorial methodology for monitoring the labor market, according to which a sociological and expert survey was conducted among employers $(\mathrm{N} 1=46)$ and graduates of the Program (N2=152), representing 32 regions of Russia where the Presidential Program is implemented most actively. The data obtained in the course of the sociological study made it possible to assess the quality of educational programs, the importance of competencies for contemporary executives, and identify several problems in the implementation of the Presidential Program. Despite the high level of quality of training, the level of demand for training under the Presidential Program was quite low. The survey revealed a problem, such as a shortage of managerial human resources with engineering and technical education. Keywords: quality of education, competencies of executives, needs monitoring, labor market.
\end{abstract}

\section{Introduction}

Education is one of the national priorities of Russia. In the context of the global transformation of the economy and society, the needs of the labor market are changing, including the quality of professional training of executives working in priority sectors of the national economy [1]. Since 1998, the Russian Federation has been implementing the state program for training managerial human resources for priority sectors of the national

${ }^{*}$ Corresponding author: mvryazantseva@,fa.ru 
economy. New challenges of the modern economy and society require changes in this program, orientation to digital transformation, and development of digital competencies of executives [2-4].

Decision-making in various areas, including the training process management of the managerial human resources for the economy, is impossible without up-to-date and timely information about the situation on the labor market [5].

A review of Russian and foreign publications summarizing various approaches to the implementation of labor market monitoring has shown that there is no standard methodology for its implementation. Internationally, labor market monitoring is based on three basic approaches [6].

The first, the European approach, is based on regular monitoring of a large number of unbiased indicators of the labor market to form various databases that are used for making various decisions. The second approach (American) is based on competency models. The third approach is based on the competency model of the future market and Industry 4.0 [7].

The scientific literature describes various methods of labor market monitoring, designed to collect information necessary for making specific decisions [8, 9]. The most universal monitoring method is proposed by the American Association for Public Opinion Research [10]. This methodology is based on a sociological study of labor market actors.

The problems of forecasting the need for managerial personnel are widely covered in the scientific community. In the world practice, there are two approaches: 1) organizational and normative, oriented to the development of the forecast for the numerical composition of managerial human resources, and 2) competence-substantive, which forms forecast through the list of sought-after competencies [11, 12].

The purpose of the present study was to develop a methodology for monitoring the labor market to assess the quality of management training and identify the needs of regions and employers in managerial human resources.

The methodology for monitoring the labor market to identify the needs and satisfaction (performance) of managerial human resources training for organizations of the national economy of the Russian Federation (hereinafter referred to as the monitoring methodology) was developed according to the state assignment of the Financial University under the Government of the Russian Federation for 2020.

To assess the quality of the managerial human resources training system, the following hypotheses have been formulated:

H1: The managerial human resources training system under the Presidential Program is effective;

H2: Professional, digital, and social competencies are the most important for today's managers.

The scientific novelty of the work consists in developing a methodology for the labor market monitoring, whose results can be used in decision-making regarding the Presidential Program management and reorganization.

\section{Methods}

The research methodology was based on Russian and foreign experience $[10,13]$. The empirical basis of the research included the results of an expert telephone survey of employers who had sent their employees to study under the Program, as well as an online survey of graduates of the 2015-2019 Program. 


\section{Results}

Based on the analysis of the Russian and foreign experience of labor market monitoring, as well as learning some implementation techniques of the labor market monitoring and their results (the analysis of the labor market monitoring organized by the Higher School of Economics (HSE), the Russian Public Opinion Research Center (VTsIOM), O’Net), the authors developed and tested a method for monitoring labor market to identify needs and satisfaction (effectiveness) in terms of training managerial human resources for organizations of the national economy of the Russian Federation, according to which an empirical study was organized and conducted.

Empirical data were collected through a telephone expert survey and an online questionnaire. The survey was conducted among employers and graduates of the 2015-2019 Presidential Program. In the course of collecting empirical data, employers and graduates showed a low level of motivation to participate in the survey due to the regularly conducted similar studies, which negatively affected the sample size. The authors managed to survey a total of 46 employers and 152 graduates from 32 Russian regions.

\section{Discussion}

Extensive data were collected in the course of the sociological research. Each of the questionnaires included more than 100 questions. In this article, the focus is only on assessing the quality and effectiveness of training in the framework of the Presidential Program.

The quality of training in the Program was considered a total of needs met during the training process (Table 1$)$.

Table 1. Indicator framework characterizing the quality of training in the Presidential Program.

\begin{tabular}{|l|l|c|}
\hline No. & \multicolumn{1}{|c|}{ Indicator } & $\begin{array}{c}\text { Percentage of } \\
\text { respondents, } \\
\%\end{array}$ \\
\hline 1 & Program content (completeness of compliance) & 100 \\
\hline 2 & Positive development dynamics of managerial competencies & 90 \\
\hline 3 & Complete satisfaction with the quality of learning materials & 56 \\
\hline 4 & $\begin{array}{l}\text { The high significance of training in the framework of the Program for } \\
\text { the region's development }\end{array}$ & 51 \\
\hline 5 & Expectations from the program were fully met & 42,4 \\
\hline 6 & Quality of teaching (using a variety of teaching methods) & 42 \\
\hline & Average percentage & 63.4 \\
\hline
\end{tabular}

Program attendees had high requirements for the content of the Program, while the majority of respondents noted only partial compliance of the content of the Program with their expectations (57.6\%). Attendees were dissatisfied with the variety of teaching methods used by teachers. Just $42 \%$ of respondents noted that teachers used more than $50 \%$ of various active teaching methods.

Despite the high value of the average assessment of the quality and effectiveness of training (63.4\%), the content analysis of open questions allowed identifying areas for improving the quality of training. This meant using more practice-oriented cases in the learning process, including those containing the best foreign and domestic practices, increasing the number of practical classes, wider use of business and role-playing games in the learning process, and methods of situational modeling. Both graduates and employers 
were unanimous in the need for more extensive involvement of practitioner teachers and representatives of the real sector of the economy.

Several recommendations addressed the need to implement some organizational measures. Experts suggested more active use of digital technologies both in the training process and in the selection of candidates for the Program; in particular, it was proposed to implement a system of online interviews with applicants.

To correct the content of educational programs, the importance of certain competency groups for the digital economy executives was assessed. The averaged responses of program graduates and employers are shown in Fig. 1.

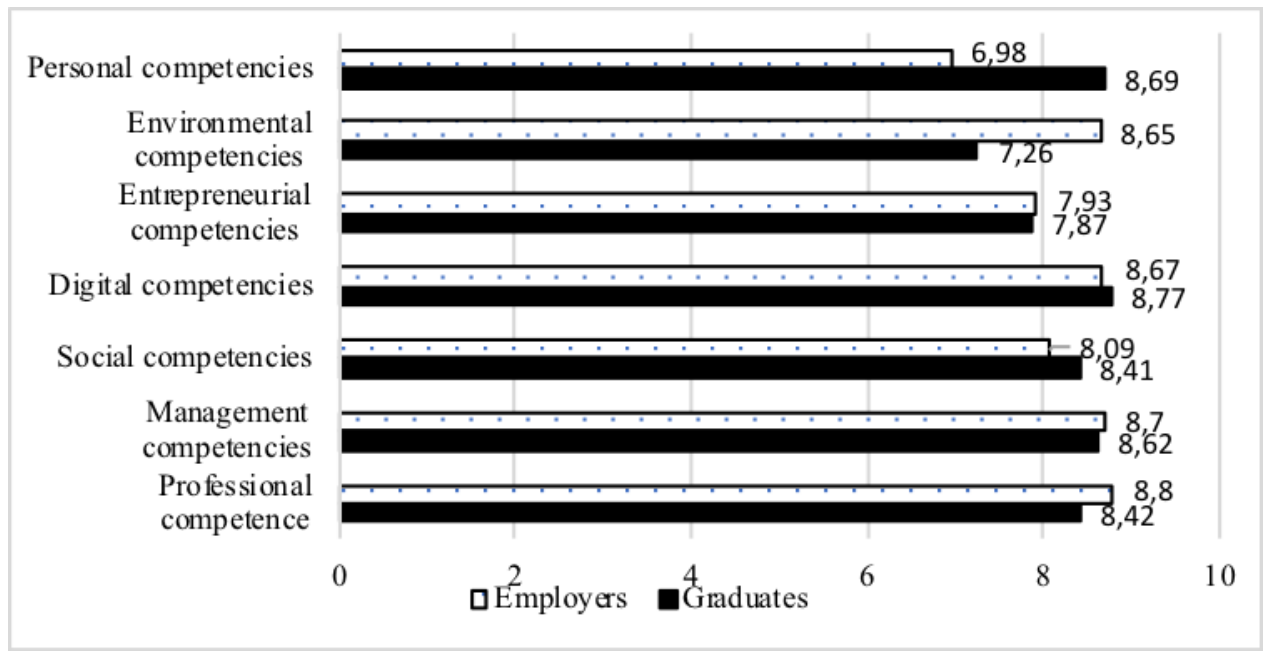

Fig. 1. Comparative analysis of the importance of different competency groups for a contemporary executive (the assessment was carried out on a 10-point scale: 1 - unimportant, and 10 - very important).

Respondents assessed the importance of certain competency groups for a contemporary executive on a 10-point scale, where one meant unimportant, while 10 meant very important. The empirical results confirmed the $\mathrm{H}_{2}$ hypothesis about the importance of professional, social, and digital competencies for a contemporary executive. Despite differences in the ratings of program graduates and employers, the calculation of differences between the samples according to the Mann-Whitney U-test has shown that they were insignificant $(\mathrm{p}=0.05)$ (Table 2$)$.

Table 2. Results of assessing the consistency of respondents' opinions based on the MannWhitney U-test

\begin{tabular}{|c|c|c|}
\hline No. & Name of the competency group & $\begin{array}{c}\text { Empirical significance of the Mann-Whitney U- } \\
\text { test }\end{array}$ \\
\hline 1 & Professional competency & $4,027.5$ \\
\hline 2 & Management competencies & $3,707.5$ \\
\hline 3 & Social competencies & $3,535.5$ \\
\hline 4 & Digital competencies & $3,788.5$ \\
\hline 5 & Personal competencies & $4,832.5$ \\
\hline 6 & Environmental competencies & 5,446 \\
\hline 7 & Ethical competencies & 2,426 \\
\hline
\end{tabular}




\section{Conclusion}

Despite the difficulties of collecting empirical data, the developed methodology and the results of the sociological survey have allowed drawing the following conclusions.

1. Hypothesis H1 about the effectiveness of training executives for priority sectors of the national economy and the high quality of training in the Program was confirmed. The opinions of the majority of respondents, both employers and graduates, indicated high quality of training of Program graduates (according to the Mann-Whitney U-test, the differences between assessments were insignificant). Similar assessments of the effectiveness in training on the Presidential Program were obtained in previous studies [14, $15]$.

2. According to the labor market estimates, managerial human resources of national economy organizations still remain demanded. The labor market clearly defines what qualities are necessary for contemporary executives, and is ready to train them accordingly.

3. As follows from the results of the survey, the target group for training under the Presidential Program consists of middle-ranking managers (deputy executives and line managers).

4. The program for training managerial human resources for priority sectors of the economy, which has been implemented since 1998, requires additional measures to improve its status in the market of educational programs. On the one hand, there is nonuniform readiness of national economy organizations to send employees for training under the Presidential Program, while on the other hand, there is a demand for the professional development of management personnel, but this can be any educational program (MBA, master's programs, advanced training courses, etc.), and not just the Presidential Program. The problem of demand for the Presidential Program is caused both by purely economic factors (some organizations experience difficulties with financing the participation of their candidates in the Program) and by high competition among educational services.

5. The results of the study indicate an overabundance of economic specialists and a shortage of executives with technical and engineering background and corresponding work experience. There is a steady demand for educational programs that ensure the digitalization of business processes in the organization.

6. The study has confirmed the hypothesis about the growing importance of professional, digital, and social competencies for a contemporary executive. The role of social competencies for the future of the labor market is consistent with the results of research conducted earlier [16], as well as with research of [7].

\section{References}

1. P. Luksha, J. Cubista, A. Laszlo, M. Popovich, I. Ninenko, Educational ecosystems for societal transformational (Global education future, Moscow, 2018). Accessed on: December 20, 2020. [Online]. Available: http://www.globaledufutures.org/images/people/GEF_april26-min.pdf

2. OECD, Innovating Education and Educating for Innovation: The Power of Digital Technologies and Skills (OECD publishing, Paris, 2016). https://doi.org/10.1787/9789264265097-en

3. T. Balliester, A. Elsheikhi, The Future of Work: A Literature Review, Research Department Working Paper No. 29 (International Labour Office, Geneva, 2018). Accessed on: December 20, 2020. [Online]. Available: 
https://www.ilo.org/wcmsp5/groups/public/---dgreports/--inst/documents/publication/wcms_625866.pdf

4. M.V. Ryazantseva, Ekonomika. Nalogi. Pravo, 12(6), 77-85 (2019)

5. T. Sparreboom, Labour Market Information and Analysis system, in Perspectives on Labour Economics for Development, 255-280 (International Labour Organization, Geneva, 2013)

6. V.N. Bobkov, Uroven zhizni naseleniya regionov Rossii, 3(209), 89-91 (2018)

7. World Economic Forum, The Future of Jobs Employment, Skills and Workforce Strategy for the Fourth Industrial Revolution (World Economic Forum, Geneva, 2016). Accessed on: December 20, 2020. [Online]. Available: http://www3.weforum.org/docs/WEF_Future_of_Jobs.pdf

8. D.D. Gilbride, F. Burr, Journal of Job Placement, 9(2), 13-17 (1993)

9. D.E. Berens, R.O. Weed, The role of the vocational rehabilitation counselor in life care planning, in Life care planning and case management handbook, 41-61 (Routledge, New York, 2018)

10. M. Barros-Bailey, The Rehabilitation Professional, 20(1), 1-10 (2012)

11. European Centre for the Development of Vocational Training (Cedefop), Skills supply and demand in Europe: medium-term forecast up to 2020 (Publications Office of the European Union, Luxemburg, 2010). Accessed on: December 20, 2020. [Online]. Available: https://www.cedefop.europa.eu/files/3052_en.pdf

12. R. Cavagnini, M. Hewitt, F.Maggioni, International Journal of Production Economics, 225, 107590 (2020)

13. I. Pietschmann, S. Kapsos, E. Bourmpoula, Z. Sajaia, M. Lokshin, Key Labor Market Indicators (International Labour Organization, Geneva, 2016). Accessed on: December 20, 2020. [Online]. Available: https://www.ilo.org/wcmsp5/groups/public/--dgreports/---dcomm/---publ/documents/publication/wcms_519717.pdf

14. A.A. Gorodnova, Y.B. Abrosimova, Bulletin of Lobachevsky State University of Nizhny Novgorod. Series: Social Sciences, 4(36), 123-129 (2014)

15. L.V. Kartashova, O.V. Tolstyakova, Bulletin of Plekhanov Russian University of Economics, 1(91), 81-92 (2017)

16. L.V. Vlasenko, M.V. Ryazantseva, I.A Ivanova, Modern Journal of Language Teaching Methods, 8(11), 680-688 (2018)

17. V.M. Zakharov, Belgorod State University Scientific bulletin. Philosophy Sociology Law, 23((166)26), 76 (2013) 